\title{
DEVELOPING STUDENTS' STARTUP BUSINESS THROUGH IMPLEMENTATION OF ENTREPRENEURIAL LEARNING MODEL
}

\author{
Jony Oktavian Haryanto ${ }^{1}$, Donald Samuel Slamet Santosa ${ }^{2}$, Andi Ina Yustina ${ }^{3}$, \\ Rendika Nugraha ${ }^{4}$ \\ ${ }^{1}$ Management Technology, Faculty of Business, President University \\ Email: jony.haryanto@president.ac.id \\ ${ }^{2}$ Elementary Teacher Education, Faculty of Humanities, President University \\ Email: dsamuel@president.ac.id \\ ${ }^{3}$ Accounting, Faculty of Business, President University \\ Email: a.inayustina@president.ac.id \\ ${ }^{4}$ Business Administration, Faculty of Business, President University \\ Email: rendika@president.ac.id
}

\begin{abstract}
ABSTRAK
Studi ini berangkat dari kesulitan mahasiswa di Indonesia untuk mengembangkan startup bisnis. Sebagian besar mahassiwa membuat bisnis di bidang makanan dan minuman, walaupun mereka tidak berkuliah di program studi kuliner, teknologi pangan, atau program studi lain yang berbasis makanan. Masalah ini mengindikasi bahwa mahasiswa tidak memiliki semangat kewirausahaan yang baik.Untuk membantu mahasiswa dalam mengembangkan startup bisnis, maka dilakukan penelitian tindakan dengan menerapkan Entrepreneurial Learning Model (ELM). Langkah utama dalam ELM meliputi training, education, experience, dan mentoring. Model ini telah dijalankan selama 6 bulan (Mei hingga Oktober 2020) pada 10 kelompok mahasiswa (yang mengembangkan 10 startup bisnis). Hasil penelitian ini adalah: (1) Mahasiswa mampu mengembangkan startup bisnis mereka; (2) Startup bisnis dikembangkan berdasarkan ide kreatif mahasiswa; (3) Mahasiswa mampu mengelola bisnis mereka. Berdasarkan hasil penelitian ini, direkomendasikan untuk menggunakan model ELM ini untuk mengembangkan startup bisnis mahasiswa.
\end{abstract}

Kata Kunci:ELM, Startup Bisnis Mahasiswa

\section{ABSTRACT}

This study starts from difficulties of university students in Indonesia to develop start up business. Most of the students make business in food and beverages, although they are not majoring in culinary art, food technology, or other food based major. The problem indicate that students have no good entrepreneurial spirit. To solve the problem, this action research will implement a method, namely Entrepreneurial Learning Model (ELM). The steps of ELM are: training, education, experience, and mentoring. This model has already run for 6 months (May to October 2020) to 10 groups of students (who make 10 startup business). The results of this research are: (1) students able to develop their startup business; (2) the startup business come from their innovative idea; and (3) students able to maintain their business. Based on the results, it is recommended to use the ELM model on developing students' startup business.

Key Words: ELM, Students' Startup Business 


\section{A. BACK GROUND}

Entrepreneurs are the important and strategic for Indonesian economy. Based on the data of Global Entrepreneurship and Development Institute (GEDI), Indonesia have rank of 94 out of 137 countries in Global Entrepreneurship Index (GEI). This very low position should not happen any more in Indonesia (as 1-Trillion dollar GDP country). Based on the conditions, increasing number and quality of entrepreneur are the big needs.

President University, as one of the leading private universities in Indonesia, strives to contribute to this. The university president deems it necessary to prepare students so that they have specific abilities and characteristics in the field of entrepreneurship. This specific capability is stated in the vision of the President University, which is "Being a superior university, producing leaders who have an entrepreneurial spirit based on a multicultural mindset and global outlook". In this vision, there is an entrepreneurial spirit as one of the graduates' characteristics.

To realize this vision, various methods are used, one of which is to develop an entrepreneurial curriculum. Entrepreneurship courses are divided into several series, some of which are compulsory subjects, and the other part is elective courses. This series of courses starts from the beginning of the semester (as compulsory courses), and starts mid-term studies (as elective courses).

At the beginning of the semester, many entrepreneurship courses provide theories or basics on which students are beginning to be equipped, and are mandatory for all students to take. These initial courses also aim to shape entrepreneurial attitudes among students. The courses in question are Entrepreneurship 1,2, and 3. With the foundation or attitudes needed to become entrepreneurs, it is expected that in subsequent courses students can practice the theory and ability well.

The elective courses are held in the middle of the student's study period, and are a continuation of the previously required compulsory courses. In this elective course, students are expected to practice entrepreneurial theories or attitudes that have been obtained from previous courses. This course consists of corporate entrepreneurship 1, 2, and 3. In groups, students can make their business or company (startup), which later will get funding.

The existence of adequate training (through 3 entrepreneurship courses), logically will make students have souls or good entrepreneurial attitudes. Some of the intended entrepreneurial attitudes include creativity, innovation, the courage to take risks, the ability to think out of the box, as well as other attitudes that can support the work done.

The reality that occurs shows different things from these ideals. This fact is found in students who take entrepreneurship courses as elective courses, especially in Corporate Entrepreneurship 1. Students seem to have no good entrepreneurial attitudes as idealized. This is ironic because students have followed basic courses aimed at shaping these attitudes, namely in Entrepreneurship 1 to Entrepreneurship 3.

The observation shows that students prefer to do business in the culinary field. Of the 20 student groups, 16 of them chose to make a business in the culinary field. Only 4 groups of students chose to develop a business other than a culinary business. When explored through interviews with students, they recognize that business in the culinary field is quite close to the daily lives of students, and is quite easy to carry out. In addition, students assume that the level of risk of failure from the culinary business is relatively small, and would be suitable for anyone to do. In addition, the existence of a clear and relatively close market share with students is also a consideration for selection.

Based on the problem, it appears that there are various causes of the problem that can be hypothesized. In general, the lack of entrepreneurial attitudes in students is possible as a result of the failure of the education or learning system that has been implemented 
previously. If this problem is allowed to drag on without any improvement efforts, it is feared that students will have the wrong concept of entrepreneurship. This can have an impact on the failure of achieving the vision of the President University (especially in the case of graduates who have an entrepreneurial spirit), and it will further impact on the poorquality of President University graduates in the context of entrepreneurship.

Starting from this thought, it is very strategic if improvements are made to the entrepreneurship education undertaken. Education needs to include various components such as curriculum, learning process, learning resources and media, quality of educators, and evaluation process. With the new design, it is expected that the quality of students will improve, especially in terms of entrepreneurial attitudes (as outputs of entrepreneurship 1-3 courses), and the start-up created by students (as outputs of corporate entrepreneurship 1- 3 courses). These things will be explained in the next chapter in this proposal.

So that the program can be carried out systematically and contain formal benefits, the program is carried out with the Entrepreneurship Development Program scheme. This scheme is one part of the action research Program. The title of this program is "Creation of Student Business Startups Through the Implementation of the Entrepreneurial Learning Model".

\section{B. THEORETICAL REVIEW}

The tendency to find convenience, avoid risk, and not be able to look for innovations outside of student life is a serious problem in the implementation of the entrepreneurship curriculum at President University. The emergence of culinary business ideas in the absence of a culinary study program at the University of the President makes the entrepreneurship program or curriculum need to be reviewed or revised.

Students' fears of failure or inadequacy of products made can be reviewed or overcome in a number of ways. Andriyanto and Haryanto (2011) stated that the decision to purchase a product can be improved through "word of mouth" which can be facilitated by the internet. Thus, students should not have to worry about selling goods or services that are their production targets. Students only need to optimize marketing strategies by increasing the intensity of word of mouth. This can be facilitated by programs on the internet.

The future market is indeed difficult to predict. However, Rita, Priyanto, Andadari and Haryanto (2018) once made a study of strategies for entrepreneurs (especially small businesses) to anticipate future markets. This study suggests the need for a learning process for entrepreneurs. Thus, this study is very relevant to the existence of student entrepreneurship which is the main study in this PPM program. The existence of introductory courses or compulsory subjects becomes very strategic in this effort.

The learning process, especially in the field of entrepreneurship can be developed in a wider scope, with the presence of Entrepreneurship education. For this reason, the article written by Priyanto (2009) is very strategic. This is because education has a broader scope or scope compared to the learning process. In other words, the learning process is only one part of education.

Rahadi (2018) said that the entrepreneurial spirit (especially in creative economy) should begin by creativity. To start the business, it can be start from small or medium enterprise. Then the business will growth following the life cycle of business. The key word to avoid decline condition is creativity.

After the business startup developed, it need to be maintained. Collective maintain will be better than self-maintain. To do the collective maintain, the startup can run the business together or make a group (such cooperative) (Santosa\&Putri, 2018). By running the business together, startup can help one each other to growth together. 


\section{METHOD}

The method of this research is action research that directly used to solve the problem. To solve the problem, this research will implement Entrepreneurial Learning Model to develop students' startup business. This action research use Kurt Lewin Model of action research that consist of 4 major steps: Plan, Act, Observe, and Reflect as this following picture:

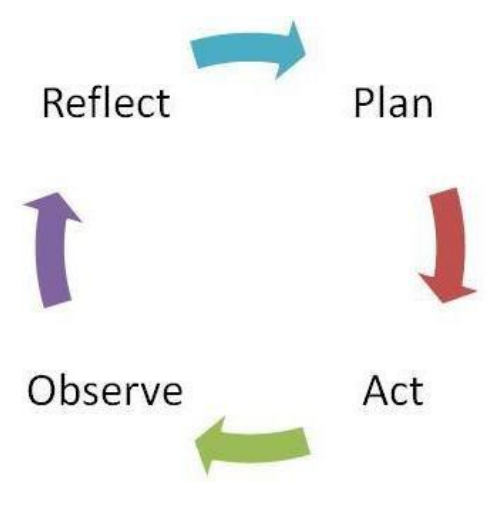

Figure 1. Kurt Lewin Action Research Model

Each cycle of action research conduct 4 steps of ELM: training, education, experience, and mentoring. This model has already run for 6 months (May to October 2020) to 10 groups of students (who make 10 startup business). All of this research conducted in 2 cycles of the Kurt Lewin Model.

The qualitative data collected by interview, Focus Group Discussion and Observation. To validate the data, this research conduct source and technique triangulation. Valid data analyzed using Miles and Hubberman qualitative analysis technique.

\section{RESULTS AND DISCUSSION}

The research has already run as the planning. Treatment (Entrepreneurial Learning Model) run twice (in 2 cycle of Kurt Lewin model), that consist of main steps ofELM. Thesteps on this researchare as follow:

1. Preparation stage

a. Socialization of "entrepreneurship development program" to students

b. Early stage participant selection

c. Preparatory material briefing for students who pass the selection

2. Beefing Steps. The activities are divided into several activities:

a. Entrepreneurship/technopreneurships seminar. This activity is held to encourage students' interest to become technopreneur. The material provided in this seminar covers the nature of entrepreneurship, entrepreneurial characteristics, ways to enter the business world, tips on becoming a successful entrepreneur, sources of funding, taking into account the risks that may occur.

b. Training on creative and innovative thinking. This training activity tips on exploring business ideas, seeing potential sources of opportunities, exploring the abilities and knowledge of participants.

c. Business ideas selection. After students take part in seminars and training in activity 2 , interested students are asked to submit ideas/business ideas nuanced technopreneur. The incoming business ideas will be selected by the judges. 
d. Business plan development workshop. For participants whose business ideas have passed the selection of ideas, the next activity will be followed by training in preparing a business plan and preparation for business establishment. In business planning training, material will be given about vision, mission, business proposals, business operations, market analysis and marketing strategies, detailed investment needs and financial report projections, personnel aspects, legal aspects, and so on.

e. Business plan selection to determine grant recipients. After participating in the business plan preparation activity, participants will be given time to translate their business ideas into a business plan. From the existing business plan documents, screening will be made to determine the business plan that will receive the grant funds. The selection is carried out by an integrated team from university, the business world and banking.

f. Apprenticeship of participants who pass the selection to SME/business world.

3. Stage of Implementation

a. Giving grants to participants who pass the selection. Realization of disbursement of grant funds to businesses that pass the selection in accordance with the agreed terms and conditions.

b. Assistance and monitoring. Assistance activities are carried out by appointing a lecturer to accompany the implementation of the establishment of a new business for a period of 6 months (the age of the grant). In this range, activities will be carried out: (1) Business consulting; (2) Bookkeeping training; (3) Training on business development strategies; (4) Monitoring. 4. Follow-up.

c. After the program ends, the university will continue to monitor and evaluate the recipient of grant funds and institutionalize program in university.

This program runs in accordance with the designs previously prepared. The stages of activities in each design are similar with as follows. In preparation stage, this research conduct socialization of "entrepreneurship development program" to students. The socialization process has made using social media (email) that blasted to all of the entrepreneurship students. In this socialization, the team inform to all of the students to joining program.

In the Beefing Steps, the activities are divided into several activities, beginning by Entrepreneurship/technopreneurships seminar. Around 180 students joined this seminar. All of them tested in context of entrepreneurial intelligence. The data of entrepreneurial intelligence tested the differences between students who come from entrepreneur family and no entrepreneur family. The result of the research is there are differences between students who come from entrepreneur family and no entrepreneur family in context of entrepreneurial intelligence. In this context, entrepreneurial intelligence of the students who come from entrepreneur family are higher than students who do not come from entrepreneur family. The event following by training on creative and innovative thinking. This training activity tips on exploring business ideas, seeing potential sources of opportunities, exploring the abilities and knowledge of participants. The trainer use training media, such as power point, motivation training, etc.

The next step is business ideas selection. After students take part in seminars and training in activity 2, interested students are asked to submit ideas / business ideas nuanced technopreneur. The incoming business ideas will be selected by the judges. Then, in business plan development workshop. For participants whose business ideas have passed the selection of ideas, the next activity will be followed by training in preparing a business plan and preparation for business establishment. In business planning training, material will be given about vision, mission, business proposals, business operations, market analysis and marketing 
strategies, detailed investment needs and financial report projections, personnel aspects, legal aspects, and so on. There are 50 participants of this activity (group).

Business plan selection to determine grant recipients. After participating in the business plan preparation activity, participants will be given time to translate their business ideas into a business plan. From the existing business plan documents, screening will be made to determine the business plan that will receive the grant funds. The selection is carried out by an integrated team from university, the business world and banking. There are 27 group that selected.Apprenticeship of participants who pass the selection to SME/business world.

The implementation of business starting by granting of grants to participants who pass the selection. Realization of disbursement of grant funds to businesses that pass the selection in accordance with the agreed terms and conditions. Assistance activities are carried out by appointing a lecturer to accompany the implementation of the establishment of a new business for a period of 6 months (the age of the grant). In this range, activities will be carried out: (1) Business consulting; (2) Bookkeeping training; (3) Training on business development strategies; (4) Monitoring. Finally, the results of this program are 10 students' startup business. All of the students in those groups have high level of entrepreneurial intelligence. All of the tenant (10 tenants) may running their business in 2 months. Their business still growth and may bigger in the future.

This research results are in line with one of the previous research. The result by Haryanto, et. al. (2019) show that the successes of startup business depends on the entrepreneurial intelligence. This research also show that the 10 startup business are led by the students who have good entrepreneurial intelligence. Based on this discussion, it is important to develop the intelligence of the students, so they can be success on startup business development.

\section{E. CONCLUSION AND RECOMMENDATION}

Based on the results of this research, it can be summarized that the program able to develop students' startup business. There are 10 startup business that may be develop in this program. The startup business come from their innovative idea. Then the third result is students able to maintain their business.Based on this results, it can be suggested that ELM may be used to develop students' startup business.

\section{REFERENCES}

Anggie, C., Haryanto, J. O. Analysis of the Effect of Olfactory, Approach Behavior, and Experiential Marketing toward Purchase Intention. International Journal of Business. Vol 13, No. 1 (2011)

Haryanto, J. O., Santosa, D. S. S., Yustina, A. I., Nugraha, R. Entrepreneurial Intelligence Based on Business Motivation. Prosiding Seminar Ilmiah Nasional Teknologi, Sains, danSosialHumaniora (SINTESA) (2019)

Peraturan MenteriRiset, Teknologi, dan Pendidikan Tinggi No. 44 Tahun 2015 Tentang Standar Nasional Pendidikan Tinggi

Priyanto, S. H. Mengembangkan pendidikan kewirausahaan di masyarakat. Jurnal Pendidikan Non Formal dan Informal. Vol 1, No. 1 (2009) 
Rahadi, D. R. Analisis Sektor Usaha Kecil \& Menengah Menjadi Model Kewirausahaan Sosial Berbasis Ekonomi Kreatif. Firm Journal of Management Studies. Vol 3, No. 1 (2018)

Rita, R. R., Priyanto, S. H., Andadari, R. K., Haryanto, J. O. How entrepreneurs anticipate the future market: An initial approach of a future market anticipation model for small businesses. Journal of Small Business Strategy. Vol 28, No. 1 (2018)

Santosa, D. S. S., Putri, I. Y. Peran Koperasi Unit Desa Dalam Kegiatan Usaha Masyarakat. Firm Journal of Management Studies. Vol. 3, No. 2 (2018)

Slavin, R. E. Cooperative Learning: Theory, Research, and Practice. Allyn \& Bacon (1995)

Wiles, J. Leadning Curriculum Development. Corwin Press (2009) 